\title{
RECENT EVIDENCE FOR AUTOCHTHONY OF AUSTRALIAN TROPICAL AND SUBTROPICAL RAINFOREST FLORISTIC ELEMENTS
}

\author{
L. J. WeBB' 1 J. G. TRACEY ${ }^{2}$ \& L. W. JesSuP 3 \\ (Accepted for publication 16.9.1983)
}

\begin{abstract}
Webb, L. J. ${ }^{2}$ Tracey, J. G. ${ }^{2}$ \& Jessup, L. W. ${ }^{3}$ ('School of Australian Environmental Studies, Griffith University, Nathan, Queensland, Australia 4111; ${ }^{2}$ CSIRO Division of Forest Research, Atherton, Queensland, Australia 4883; ${ }^{3}$ Queensland Herbarium, Indooroopilly, Queensland, Australia 4068) 1986. Recent evidence for authochthony of Australian tropical and subtropical rainforest floristic elements. Telopea 2(6): 575-589 - Studies in continental drift suggest that much of the Australian flora is of Gondwanic origin. The fossil record shows so-called 'Indo-Malesian' and 'Antarctic' elements of the Australian flora were present in southern Australia before a land bridge with SouthEast Asia was possible, and before Australia and Antarctica were separated. Today there is a remarkable concentration and variety of families of primitive angiosperms in the rainforests of north-eastern Australia; many taxa of which are of low vagility. A recent floristic classification of Australian rainforests revealed certain patterns of outliers and disjunct and relict species assemblages interpretable by past environmental sifting. The existence of refugia of great antiquity is postulated under certain ecological conditions. The proportion of tree genera, often of low vagility, shared between homologous habitats in Australia and the Indo-Malesian region suggests common ancestry. Interspersion of rainforest and sclerophyll floras supports the theory that rainforest elements are authochthonous and archetypal, and sclerophylls largely derivative. This contrasts with traditional phytogeographic interpretations. The use of the terms 'Indo-Malesian' and 'Antarctic' to indicate sources of intrusive floral immigrants should accordingly be discontinued. Thus tropical or megatherm rainforest and monsoon forest floristic elements should be added to the subtropical (mesotherm) and temperate (microtherm) elements already recognized as remnants of the ancient Gondwanan flora that once covered Australia.
\end{abstract}

\section{INTRODUCTION}

The 120-year-old doctrine of the three elements of the Australian flora (Hooker 1860) is an important part of Australian botanical tradition, which was maintained until recently (see e.g. Burbidge 1960). It proposed that two rainforest (angiospermous) floras, the tropical Indo-Malayan and the temperate Antarctic, invaded Australia some time in the Tertiary. This was after an invasion (presumed from Asia) in the Cretaceous had supplied the ancestors of the 'Australian' element characterized by xeromorphic and mainly endemic taxa. In the absence of evidence now furnished by the modern theory of plate tectonics for land continuities during earlier geological epochs, invasions were postulated via land bridges. The history of the 'three-element invasion theory' is succinctly reviewed by Barlow (1981). In addition to land bridges, long-distance transoceanic dispersal of diaspores has also been invoked. Its modern proponents include Thorne (e.g. 1972) and Carlquist $(1974,1981)$. Objections to the land-bridge theory were raised by Herbert (e.g. 1967) who imagined the Australian rainforests as developed from 'a common palaeotropic stock'. Notably, 'the myth of long-distance dispersal' was attacked by van Steenis $(1962,1979)$. 
The classical phytogeographic picture, which still influences current interpretations of the origin of the tropical and subtropical rainforest floras, was therefore of an impoverished island continent substantially without rainforest angiosperms until the end of the Cretaceous. After that, Australia presumably received diaspores of tropical rainforest angiosperms by 'sweepstakes routes' across oceans. Meanwhile, conifers and the 'autochthonous' xeromorphic ('sclerophyll') elements were thought to have dominated the continent. During the mid-Miocene (about $15 \mathrm{~m} . \mathrm{y} . \mathrm{BP}$ ), sea gaps to the north were reduced and land contact with Sundaland would have facilitated invasions by tropical rainforest taxa (Raven \& Axelrod 1974, van Steenis 1979). Modern plate tectonics theory provides a reasonable explanation for the arrival of temperate taxa from South America via Antarctica by overland migration, and dispersal across short water gaps until about $38 \mathrm{~m} . \mathrm{y}$. BP, i.e. well into the Oligocene. Dispersal of a more 'warm temperate or even sub-tropical' flora across the Indian Ocean may also have occurred (Raven 1979).

The ancestors of the following ancient groups, some of which might be considered to be Australian autochthons because of the high degree of endemism, are supposed by Raven \& Axelrod (1974) to have reached Australia in mid-Cretaceous time from Africa, where they consider the angiosperms originated:

Annonales, Balanopales, Campanulales, Casuarinales, Commelinales, Cornales, Ericales, Epacridaceae, Euphorbiales, Liliales, Myrtales, Pittosporales, Proteales, Rosales, Santalales, Theales.

According to the fossil record, the earliest angiosperms occurred in Australia in the Albian (about 115 m.y. BP), which is about $12 \mathrm{~m} . \mathrm{y}$. after their appearance in Eurasia and West Gondwanaland (Africa and South America). We cannot, however, be sure whether this gap is real or not (Raven 1979). The climate is presumed to have been mild and humid, favouring the gradual accumulation in Australia of relict taxa of angiosperms that had originated elsewhere (Raven pers. comm.). This reasoning would exclude polyphyletic or tropical origins of what are now regarded as primitive angiosperms. However, 'secondary mesophytic lines' of angiosperms persisted in favourable niches, notably in north Queensland and New Caledonia (Raven \& Axelrod 1974). As Takhtajan (1969) notes, the most primitive angiosperms survive today not on the tropical humid lowlands but on the adjacent cooler and equable uplands.

The meagre fossil pollen records during the Cretaceous and early Tertiary for northern Australia and Papua New Guinea (e.g. Harris 1965; Hekel 1972; Khan 1974, 1976; Muller 1981) do not support the idea of in situ origin of early angiosperms on this part of the Australian plate. Lacking validation of their antiquity from the fossil record, the remarkable array of primitive angiosperms that survive today in the north Queensland rainforests (Webb \& Tracey 1981a) has been interpreted as immigrant, and not autochthonous.

Such an interpretation is reminiscent of the classical 'invasion' theories. While there has been considerable modification of the earlier doctrine (see e.g. Barlow 1981, Specht 1981a,b for references), it cannot yet be said that the origins and times of arrival of the rainforest floras, especially the tropical and subtropical ones, are properly understood. 
This paper examines ecological evidence recently established for Australian rainforests (e.g. O'Neill 1980, Webb \& Tracey 1981a, Webb et al. 1983) in an attempt to clarify some of the possibilities for autochthony of elements of the tropical and subtropical rainforest vegetation in Australia.

Special attention is drawn to the following ecological factors that are considered relevant but generally overlooked:

(1) The low vagility of many rainforest taxa, i.e. large size and very limited viability (perhaps less than 2 to 3 weeks) of certain diaspores, especially those in late stages of succession.

(2) The almost complete lack of data about transport of diaspores over 'medium' or 'long' distances $(50-200 \mathrm{~km}$ and $200-500 \mathrm{~km}$ respectively, according to van Steenis 1962, 1979). This involves strictures not only of size and viability of diaspores as in (1), but also bird migration pathways via habitats suitable for certain rainforest plants, seasonality, etc.

(3) The critical importance of ecesis, irrespective of diaspore transport, i.e. availability on already vegetated land of favourable niches for seed germination and seedling establishment, leading to successful breeding populations. Dioecious species would be especially disadvantaged.

(4) The erratic correlations between actual distribution of plants and their vagility (inferred from diaspore morphology). This is a corollary of (2) because of lack of direct observations, and a corollary of (3) because of the erratic distribution of sites to which particular taxa are adapted.

(5) The obligate association of species of synusiae within rainforests that requires migration 'in unison' (cf. Webb \& Tracey 1981a). For example, the arrival and potential establishment of diaspores have to be co-ordinated in space and time to allow for the following integrations: trees with different light requirements in different forest strata and at different stages of succession; epiphytes and lianes that require trees for support; ground-layer herbs that require a certain microclimate provided by the canopy; rhizosphere microflora dependent on higher plants, and vice versa; and so on. This obligate interdependence of life forms would have decreased the probability of recurrent migrations producing similar rainforest community types over extensive areas of heterogeneous sites remote from seed sources.

(6) The abundance of disjunct but closely related rainforest community types throughout northern and eastern Australia, now separated by ecological barriers of different kinds, and often occupying several different environment types. These 'community-floristic' relationships have only been appreciated more precisely following a recent comprehensive floristic classification (Webb \& Tracey 1981a, b; Webb et al. 1983). The extraordinary relict distributions of many ancient Australian taxa are better known, e.g. Livistona (Palmae) (Dransfield 1981).

(7) The availability of presumably ancient and stable refugia of various kinds in Australia, which have conserved a network of isolated but related community types (Webb \& Tracey 1981a). This interpretation follows that of "vicariance biogeography" (Wiley 1980), which limits the possibilities and needs for de novo colonization by medium and long-distance dispersal (Carlquist 1981).

(8) The floristic affinities at the generic level of 'homologous' rainforest communities in matched habitats in Australia and neighbouring continents and islands (for which there is now geophysical evidence for Cretaceous and early 
Tertiary land continuity or approximation to permit joint inheritance of ancient floral stocks).

(9) The segregation of the rainforest floras and the sclerophyll flora has been exaggerated, probably mainly because of traditional assumptions about the antiquity and dominance of the sclerophyll element, and the 'alien and invasive' nature of the rainforests. Certain extant phylogenetic links (e.g. Proteaceae), composition and ecological relations of ecotonal communities and species interspersion on certain soils may well provide keys to evolution and co-adaptation of the different floras from the earliest times.

(10) The separate identity - distinct from tropical monsoonal, tropical humid, and temperate (montane) types - of the subtropical rainforest element (Webb et al. 1983). It is characteristically associated with Araucaria in moist areas along the north-eastern Australian coast. In somewhat drier subcoastal areas it loses Araucaria, becomes dominated by Brachychiton spp. and intergrades with Acacia spp. Whereas it is well represented in the south, its scattered distribution in the north of Queensland may indicate relicts of a previously cool moist climate that favoured conifers and early angiosperms (Webb \& Tracey 1981a). The subtropical rainforests may therefore be of great palaeoecological significance.

\section{COMMENTS ON THE PALAEOGEOGRAPHIC EVIDENCE}

Although, as van Steenis (1979) commented, we may accept the reality of the geophysical basis for plant geography in East Malesia, we may also doubt that it has 'reached an acceptable degree of stability'. A similar remark seems relevant to the Australian fossil record, which has many important gaps in time and space.

Keast (1981) recently concluded that the biggest single problem of Australian plant biogeography surrounds the pathway by which not only the angiosperms but also the tropical and subtropical genera of rainforest plants reached Australia'. This echoes Raven's (1979) reference to the 'fundamental dilemma concerning the route and method of dispersal of terrestrial organisms between the northern and southern hemispheres' during late Cretaceous and Palaeogene time.

The present paper is not concerned with degrees of speculation about such early mechanisms. It is nevertheless pertinent to select a few botanical conclusions from the fossil evidence, incomplete as it is.

1. Barlow (1981) states that "the temperate and subtropical rainforests of eastern Australia ... (are) the remnants ... of the ancient Gondwanan flora which covered the entire continent when it was still attached to Antarctica sixty million years ago. They are the surviving residue of the primitive stocks from which the bulk of the modern Australian flora has been derived'. However, Barlow made no reference to the status or history of the tropical monsoonal and tropical humid (mildly seasonal) rainforests of northern and north-eastern Australia (for discussion, see Webb et al. 1983).

2. Specht (1981a) generalized that the Indo-Malayan flora (cf. Australian 'Indo-Malesian' element) is only part of the broader Afro-Indo-MalayanAustralasian flora, and proposed an extensive subtropical-tropical Gondwanic flora, of which the Afro-Australasian and Indo-Malayan-Australasian are but persistent fragments. 
Specht $(1981 b)$ is at variance with some authorities (e.g. Raven 1979, van Steenis 1979) about the biological importance of the contact of the Australian plate with the Sunda Arcs in the mid-Miocene - ... Australasian taxa penetrated across Sundaland but not into south-east Asia. It is not known how many Sundaland taxa invaded the Australasian plate, though a few fern genera can be listed ... only a few, more mobile genera appear to have entered Australasia from the north'. Recent discussions in Whitmore (1981) indicate that migrations of certain taxa may be inferred from both directions, but that many enigmas remain in the absence of an adequate fossil record or an accepted view of evolutionary relationships within particular groups.

3. Fossil pollen evidence assembled by Martin $(1978,1981,1982)$ confirms that the first angiosperm to be reliably identified was Ilex in the mid-Cretaceous of south-eastern Australia. This taxon is now restricted to living plants in northern Australia and other tropical regions farther north. Other taxa, e.g. Nypa (Churchill 1973, Partridge 1976), now confined to the tropics, occur in the early Tertiary in southern Australia, and provide further evidence for the former distribution of tropical rainforest types throughout Australia. Thus taxa belonging to the so-called 'Indo-Malesian' element were present in Australia (as part of its Gondwanic quota?) before the proximity of Australia and Sundaland in the mid-Miocene. Moreover, from the early Miocene onwards, spreading aridity in Australia replaced much of the moist forests by woodlands, scrubs and grasslands, and witnessed the explosive evolution of the scleromorphic flora characterized by Eucalyptus and Acacia (Martin 1978, 1981; Galloway \& Kemp 1981). Thus the immigration of Indo-Malesian elements during the midMiocene would not have been favoured except in moist warm habitats along the northern and eastern coasts.

4. A physiognomic analysis of Eocene leaf floras of south-eastern Australia suggests that these deposits represent very diverse but more homogeneous rainforest types of the complex wet subtropical, and possibly simpler wet tropical formations now found from northern New South Wales northwards in Queensland (Christophel 1981). Because physiognomic analysis is based on exposed sun-leaves of the canopy (Webb 1959, 1968), the inclusion of leaves preserved as fossils from all forest layers, including shade-leaves of the understorey, would increase the proportion of larger leaves. This would tend to bias the classification of the forest site towards tropicality. However, the species diversity and high proportion of entire leaves found as fossils in the oligotrophic mudstones in the Eocene are characteristic only of modern tropical and subtropical wet types on strongly acid oligotrophic clays. Temperate types on the latter soils have relatively low species diversity and mostly toothed leaves.

Another source of bias in preservation of plant remains is that some leaves (e.g. Quintinia), and some pollens (e.g. Lauraceae) do not preserve well. Moreover, the conditions of wet climates are most favourable for preservation, so that the palaeobotanical record is largely that of the wetter climates (Martin 1982).

\section{ECOLOGICAL EVIDENCE}

\section{Floristic classification and community disjuncts}

A comprehensive classification of the tree flora (species and genera) of Australian rainforest communities reveals patterns of overlap and disjunction of floristic elements that can be interpreted satisfactorily only by invoking climatic 
and edaphic sifting of a much more widespread rainforest vegetation in the past (Webb et al. 1983).

The numerous 'extraneous floristic elements' extending many hundreds of kilometres outside each core area represent fragmentary but still identifiable community-types. These disjuncts are presumably the result of past climatic changes that have left favourable environmental 'islands' for survival of a type that was once more widespread. They have certain ecological resemblances to refugia elsewhere, such as the 'nunataks' (isolated summits) of boreal regions, and the 'kopjes' (bouldery hills among savanna) of South Africa. In Australia, the term 'fire shadows' is often used to describe topographic situations where rainforest patches are protected from fire. Further evidence for the relict status of the disjunct communities is discussed by Webb et al. (1983).

\section{Relict disjunct communities versus migration of rainforest taxa 'in unison'}

How is the 'archipelago of relicts and refugia' (Webb \& Tracey 1981a) represented by Australian rainforest distribution to be interpreted? Although the classification was limited to taxa of trees, many more synusiae are involved in tropical and subtropical rainforest ecosystems. These synusiae are integrated and interdependent, and together form characteristic floristic associations and combinations of life forms. The abundant disjunctions preserve a species structure and configuration of life forms that group various widely scattered types together. The combination of different synusial types, although often skeletal, remains. We consider relict status to be a more likely explanation than attributing the wide distribution and synthesis of disjunct rainforest communities to long distance dispersal by chance.

As for long-distance overland migration, Raven (1979) suggests that this was not possible, after approximately 125 m.y. BP, between Africa (where he supposes the angiosperms to have originated) and Australia via a warm temperate or subtropical route. Given the time scale available, and recognizing the low vagility of many rainforest taxa that survive today in the north-eastern and north-western Australian rainforests, the theoretical need for an 'invasion' of primitive angiosperms into Australia is debatable. As Raven (1979) notes, biota that include many parasites and other forms associated with plants scarcely could have been spread by long-distance dispersal. Similar reasoning applies to the improbability of long-distance dispersal of rainforest synusiae to transport particular ecosystems correlated with particular niches.

For temperate regions close to glacial influences, Davis (1981) takes the extreme view that forest communities are chance combinations of species that are determined by different migration patterns during each interglacial amelioration of Quaternary climate. However, in more favourable and more resourcestable environments at lower latitudes and on the time scale of the Tertiary, particular habitat and niche characteristics besides climate allow more consistent selection of successful species and species groups (cf. Southwood 1977). This produces particular assemblages of species with greatly different migration rates and degrees of vagility. Such community-types can be identified in tropical and subtropical regions, as in Tables 1 and 2. As discussed above, such types generally have numerous outliers as the result of historical changes. 


\section{ANALYSIS OF SELECTED DISJUNCT COMMUNITIES}

The disjunctions and relictual nature of rainforest distribution in Australia revealed by the floristic classification deserve further exploration, although definitive conclusions are not possible. Data for dispersal spectra of diaspores, endemism, and floristic 'balance' or 'harmony' (Daubenmire 1978) may be suggestive. These data were therefore compiled for sites selected from five different types of rainforests and monsoon forests in northern Australia in different ecofloristic provinces. The related sites within each type are often widely separated, and are listed in Table 1 . The forest types are:

(1) Semi-deciduous mesophyll and notophyll vine forests on red earth residuals and riverine strips in the moist monsoon zone (6 sites).

(2) Deciduous vine thickets on limestone, granite or basalt rock outcrops in the dry monsoon zone (6 sites).

(3) Semi-evergreen vine thickets on soils from basic volcanics in the dry subtropical subcoastal zone (6 sites).

(4) Microphyll evergreen vine-fern forests on cloudy granitic highlands in the lower montane-cool subtropical zone of the wet tropics ( 5 sites).

(5) Complex mesophyll vine forest on alluvium-colluvium in gorges in the very wet tropical lowland zone (6 sites).

The structural typology follows Webb $(1959,1968,1978)$, and the different forest types are described by Webb et al. (1983).

\section{Species vagility}

Dispersal classes follow definitions by van der Pijl (1972), and Kalkman (1979), with the addition of different size classses for endozoochores, and are given in Table 2 for tree species of the combined sites of the five different forest types of Table 1 .

The deduction of dispersal mechanism from diaspore morphology may, in the absence of direct observations, be fallacious (van der Pijl 1972). Moreover, 'means of dispersal' is not at all synonymous with 'effective dispersal', i.e. permanent establishment of the plant, and it is often impossible to find a clear correlation between dispersal capacity and distribution patterns (van Balgooy 1971, van Steenis 1979).

The data are therefore presented with these reservations in mind, recognizing that effectiveness of rainforest seed dispersal is a much neglected field of inquiry in Australia and elsewhere.

Thus certain assumptions must be made. If no other dispersal mechanism is apparent then all diaspores associated with fleshy fruits as well as mimetic and arilloid-bearing seeds are classified as endozoochorous. Where several dispersal mechanisms are involved (diplochory), only the mechanism likely to facilitate the greatest dispersal distance is considered. For example, species adapted for both hydrochory and endozoochory are listed as hydrochorous, and species adapted for both endozoochory and myrmecochory are listed as endozoochorous.

Sizes of endozoochores are based on measurement of herbarium specimens and descriptions in floras and would in most cases be minimum sizes, given that drying usually results in shrinkage. For endozoochorous species the maximum 
TABLE 1. ENDEMICITY OF TAXA RECORDED IN SELECTED COMMUNITY TYPES OF AUSTRALIAN TROPICAL AND SUBTROPICAL RAINFOREST PATCHES

\begin{tabular}{|c|c|c|c|c|c|c|}
\hline Forest types and sites & Species & Genera & Families & $\begin{array}{c}\text { Endemic } \\
\text { species } \\
\% \%\end{array}$ & $\begin{array}{c}\text { Australian } \\
\text { endemic } \\
\text { genera \% }\end{array}$ & $\begin{array}{c}\text { Papuaustralian- } \\
\text { New Caledonian } \\
\text { endemic } \\
\text { genera \% } \\
\end{array}$ \\
\hline $\begin{array}{l}\text { (1) Monsoon forests } \\
\text { Starkie-Mt Webb, Qld } \\
\text { Bamaga-Long Scrub, Qld } \\
\text { Claudie River, Qld } \\
\text { Rocky River, Qld } \\
\text { Banjo Jungle, N.T. } \\
\text { Home Hill, N.T. }\end{array}$ & $\begin{array}{r}255 \\
95 \\
73 \\
123 \\
90 \\
57 \\
46\end{array}$ & $\begin{array}{r}158 \\
72 \\
58 \\
99 \\
75 \\
51 \\
39\end{array}$ & $\begin{array}{l}58 \\
40 \\
33 \\
46 \\
38 \\
31 \\
26\end{array}$ & 45.8 & 4.4 & 3.2 \\
\hline $\begin{array}{l}\text { (2) Deciduous vine thickets on } \\
\text { rock outcrops } \\
\text { Chillagoe, Qld } \\
\text { Coen, Qld } \\
\text { Riversleigh, Qld } \\
\text { Bowen, Qld } \\
\text { Towercast, Qld } \\
\text { Mt Trafalgar, Qld }\end{array}$ & $\begin{array}{r}105 \\
33 \\
47 \\
8 \\
20 \\
18 \\
18\end{array}$ & $\begin{array}{r}70 \\
27 \\
42 \\
7 \\
19 \\
13 \\
14\end{array}$ & $\begin{array}{r}36 \\
22 \\
25 \\
5 \\
14 \\
13 \\
12\end{array}$ & 54.2 & 4.3 & 4.2 \\
\hline $\begin{array}{l}\text { (3) Subtropical dry semi- } \\
\text { evergreen vine thickets } \\
\text { Carnarvon, Qld } \\
\text { Narayen, Qld } \\
\text { Lotus Creek, Qld } \\
\text { Thangool Hill, Qld } \\
\text { Gunnedah, N.S.W. } \\
\text { Boonah, Qld }\end{array}$ & $\begin{array}{l}90 \\
34 \\
30 \\
35 \\
17 \\
13 \\
36\end{array}$ & $\begin{array}{l}65 \\
31 \\
28 \\
31 \\
14 \\
12 \\
33\end{array}$ & $\begin{array}{l}30 \\
19 \\
17 \\
22 \\
12 \\
11 \\
16\end{array}$ & 77.7 & 15.3 & 6.1 \\
\hline $\begin{array}{l}\text { (4) Cool wet cloudy highlands, } \\
\text { n. Qld } \\
\text { Mt Bartle Frere } \\
\text { Mt Bellenden Ker } \\
\text { Mt Finnigan } \\
\text { Mt Hemmant } \\
\text { Mt Spurgeon }\end{array}$ & $\begin{array}{r}128 \\
27 \\
47 \\
42 \\
52 \\
44\end{array}$ & $\begin{array}{l}85 \\
24 \\
37 \\
36 \\
41 \\
40\end{array}$ & $\begin{array}{l}39 \\
17 \\
24 \\
23 \\
27 \\
22\end{array}$ & 87.5 & 16.4 & 18.8 \\
\hline $\begin{array}{l}\text { (5) Tropical lowland gorges, } \\
\text { n. Qld } \\
\text { Baileys Creek } \\
\text { Mossman Gorge } \\
\text { Macnamee Creek } \\
\text { Gap Creek } \\
\text { Harveys Creek } \\
\text { Oliver Creek }\end{array}$ & $\begin{array}{r}262 \\
80 \\
70 \\
95 \\
88 \\
65 \\
75\end{array}$ & $\begin{array}{r}173 \\
60 \\
55 \\
73 \\
70 \\
55 \\
58\end{array}$ & $\begin{array}{l}63 \\
31 \\
28 \\
43 \\
35 \\
32 \\
33\end{array}$ & 66.0 & 19.6 & 7.0 \\
\hline
\end{tabular}

size of the diaspore that would be discarded by the animal (e.g. seed, stony endocarp of a drupe or pyrene) was measured.

Many passive ballistochores have very small but otherwise unspecialized seeds that would frequently be subject to dispersal by wind, e.g. Quintinia, Argophyllum and Leptospermum. However, in this study only those species with diaspores possessing special structures such as wings or plumes or dust-like seeds are classed as anemochorous.

In Table 2, the high percentages of endozoochorous seeds (73 to 87\%) potentially dispersed by marsupials, rodents, bats and birds (including the Cassowary) for all the sites are correlated with the predominance of succulent fruits in most rainforest taxa, in contrast to many dry capsular fruits in sclerophyll vegetation. As noted by Webb \& Tracey (1981a), speculation about 
TABLE 2. DIASPORE DISPERSAL CLASSES OF SPECIES RECORDED IN THE FIVE DIFFERENT HABITAT TYPES OF TABLE 1

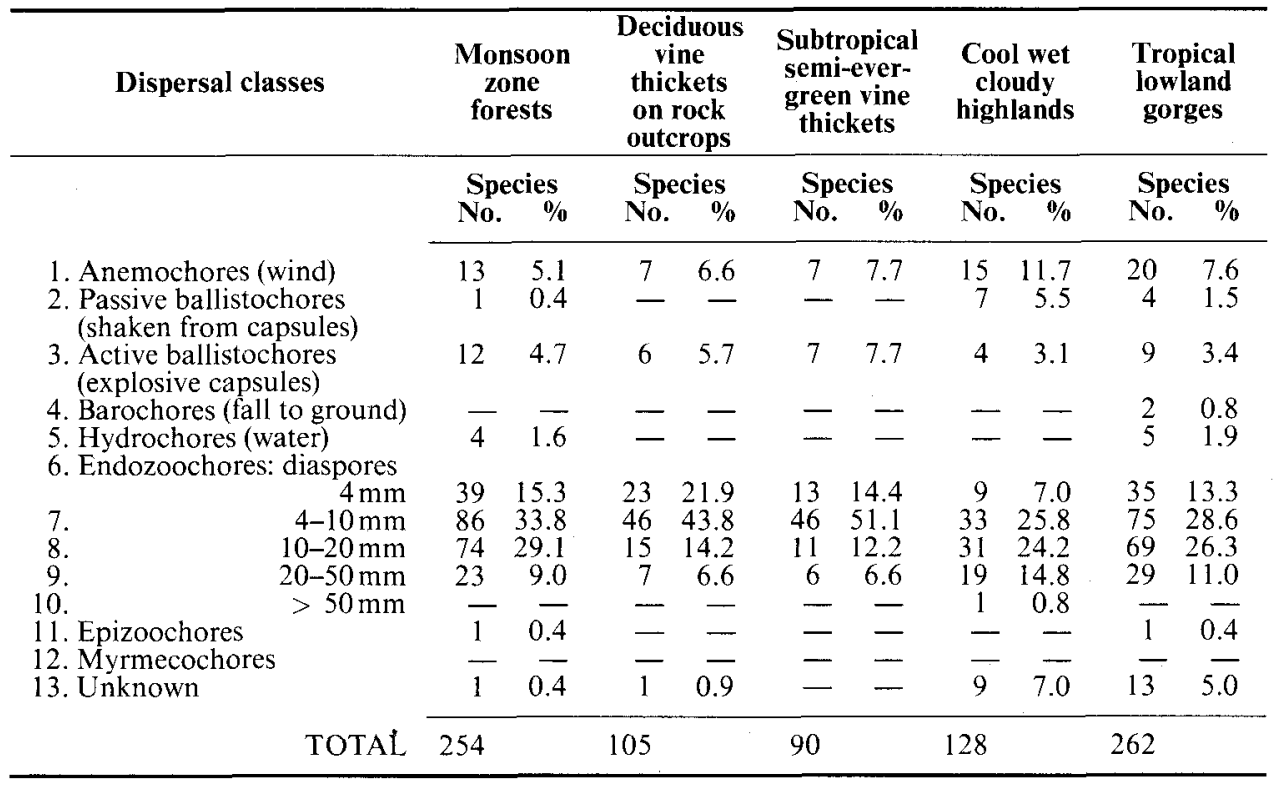

the relevance of the data for medium or long-distance dispersal by birds or bats cannot be conclusive in the absence of further detailed information. Provided that the seed is not too large, dispersal over short distances, say over a few kilometres, and even up to some tens of kilometres, may be reasonably anticipated. The recolonization of the savanna areas of the western Atherton Tableland, north Queensland, by rainforests over the last 8000-11000 years (Kershaw 1981) would have involved a maximum east-west distance of 20 to 40 kilometres on undulating basaltic topography lacking refugia during the last dry glacial period. The seed dispersal spectra for remaining fragments of rainforest at the western edge of its extent before clearing, e.g. at Tolga, are similar to those in Table 2. As pointed out by Webb \& Tracey (1981a), virtually all the tree species in these peripheral situations away from mesic or fire-proof refugia are ecological 'wides', confirming they possess a certain vagility.

Studies on the fruits and seeds of gallery forest species in Africa also indicate a predominance of endozoochory and dispersal distances 'probably not exceeding a few kilometres' (Wickens, 1979). The dispersal over wide ecological barriers of large seeds, say greater than $20 \mathrm{~mm}$ diameter, especially if they have poorly protected fleshy cotyledons (e.g. Idiospermum, Castanospermum), or if they are of restricted viability, remains arguable.

Wind dispersal accounts for 5 to $12 \%$ of the species in Table 2, and would provide very limited vagility. Van der Pijl (1972) points out that much dispersal by wind is incidental, especially during storms. Martin (1982) suggests, but without explicit evidence, that the prevailing westerlies in Australia could transport 'small seeds', and that tropical cyclones, which cause damage and disturbance to facilitate establishment of new plants, could also be effective.

Coincidentally, those sites in Table 2 that have the highest percentage of anemochores and passive ballistochores are also the most exposed to persistent 
strong winds that cause streamlining of the forest canopy on summits and upper ridges (800-1600 $\mathrm{m}$ altitude) of the coastal mountains in north Queensland.

A good example of the breakdown in correlations between distribution pattern and presumed degree of vagility is provided by ubiquitous species in the Indo-Malesian-Australian region. Over a score of species that occur in different stages of succession and not always in marginal rainforest sites can be listed throughout the region, e.g. Abrus precatorius, Allophylus cobbe, Alstonia scholaris, Anthocephalus chinensis, Bombax ceiba, Carallia brachiata, Chionanthus ramiflora, Cordia dichotoma, Dodonaea viscosa, Entada phaseoloides, Ficus racemosa, Gyrocarpus americanus, Leea indica, Macaranga tanarius, Mallotus philippensis, Melia azedarach, Morinda citrifolia, Pongamia pinnata, Securinega melanthesoides, Terminalia catappa, Toona australis and Trema orientalis.

These appear to be 'good' taxonomic species. Their methods of seed dispersal vary considerably and include presumably bird and wind distribution types. How is their vast distribution to be explained? Are they 'super-nomads' of actually great vagility, or stagnant bradytelic taxa from the earliest times?

\section{Endemism}

Analyses of the distribution of Australian rainforest genera by Webb \& Tracey (1981a) and Specht (1981a), have shown that a substantial proportion is shared throughout the Indo-Malesian-Australasian region. This may be partly the result of common descent from a Gondwanan flora, as well as of interchanges possible in mid-Miocene times. The proportions of endemic species, genera and families on each site in the ecologically very dissimilar forest types listed in the previous section are shown in Table 1.

The relatively low percentage $(4 \%)$ of endemic genera in the tropical monsoon forest types (1) and (2) is notable, and indicates the strength of floristic affinities with similar raingreen forest types in the monsoon zones of the Indo-Malesian region. The classification of genera discussed previously also indicates the floristic affinities of the rainforest cum monsoon forest types extant in north-western, northern and north-eastern Australia as far south as northern New South Wales. The wide distribution of the Australian monsoon forest genera, in contrast to that of species, implies links of greater antiquity of the raingreen forest floras.

On the other hand, there is considerably greater endemism of genera in the other types. The subtropical raingreen forests (type 3 ) presumably have different origins from the tropical ones.

The wet tropical highland and lowland rainforests (types 4 and 5) have relatively high percentages of endemic genera, suggesting long periods of isolation in Australia.

Endemism of fauna also provides corroborative evidence in those habitats such as cloudy wet mountain tops, wet lowland gorges, gallery forests in drier regions, and fire-proof rocky outcrops that function as refugia (Webb \& Tracey 1981a). Some vertebrates exhibit relictual distribution in the north Queensland region and many insects that have a geological age equivalent to that of the angiosperms show disjunctions and distribution patterns of endemics that are evidently of comparable antiquity to the plants. Although collecting is incomplete because of inaccessibility of high mountain tops, there is accumulating evidence for whole suites of flightless carabid beetles, and other flightless 
insects belonging to primitive taxa with disjunct Gondwanan distribution patterns. For example, insects have recently been discovered whose nearest relatives occur in South America (Sphaenognathus), New Zealand (Myerslopiini), New Caledonia (Notuchus, Ignambia) and south Queensland (Kumaressa, Lissapterus, Peloridiidae) (Monteith 1980; Kikkawa, Monteith \& Ingram 1981). Hence, like many of the plants, these flightless insects of very low vagility are presumably ancient Gondwanan relicts, and not recent arrivals from the north or south.

\section{Balanced floras}

The tree species of the combined sites in the five different rainforest types already described were analyzed according to the proportions of different taxa (Table 3). If, as Daubenmire (1978) explains, there were equal probabilities of all taxonomic groups migrating to a particular site, there should be a random selection of species from among the floras of neighbouring source areas. Thus large families and genera would be represented roughly in proportion to their sizes. There are of course strictures for establishment that interfere with random selection, such as dioecy and variations in environmental sensitivity of colonists.

TABLE 3. DIFFERENT RATIOS OF TAXA IN THE PATCHES OF AUSTRALIAN RAINFOREST FLORA OF TYPES IN TABLE 1 COMPARED WITH RATIOS IN AN INSULAR FLORA

\begin{tabular}{lccc}
\hline Floristic region/association & species:family & species:genus & genera:family \\
\hline Monsoon forests & 4.39 & 1.61 & 2.72 \\
Deciduous vine thickets on rock outcrops & 2.91 & 1.50 & 1.94 \\
Subtropical semi-evergreen vine thickets & 3.00 & 1.38 & 2.16 \\
Cool wet c'oudy highlands & 3.20 & 1.50 & 2.17 \\
Tropical lowland gorges & 4.15 & 1.51 & 2.74 \\
Hawaiian Islands & 17.80 & 6.80 & 2.61 \\
\hline
\end{tabular}

In isolated sites more recently available for colonization, such as oceanic islands (e.g. Hawaii), where many taxa available in neighbouring areas are found to be lacking, the floras are termed unbalanced or disharmonic. Particular habitats on land, which are separated by wide ecological barriers, and that have been isolated for long periods of time, tend to resemble insular habitats by developing disharmonic floras and many endemics (Daubenmire 1978, van Steenis 1979). The flora of the Hawaiian islands were therefore added to Table 3 for comparison, using data from St John (1973). There is considerably less balance or accordance of the flora of the Hawaiian islands in relation to species per family and species per genus, but the balance for genera per family is much the same as the Australian sites. The disharmony of the indigenous Hawaiian flora at the species level may be attributed to adaptive radiations within particular groups, favoured by the relatively large area and diversity of habitats of the Hawaiian islands compared with the Australian sites.

The similarity of balance of the two different floras at the genus level is presumably the result of at least two different factors. The old tree flora of the Australian rainforest fragments has been subject to wholesale species extinctions for very long periods of time, across a wide range of genera that are now typically monotypic or oligotypic. On the other hand, the relatively new insular flora of Hawaii has a restricted number of genera and families as the result of low and variable vagility of taxa, and the constraints of transoceanic long-distance dispersal. 


\section{CONCLUSIONS}

New definitions of degrees of autochthony of elements of the Australian flora hinge on discarding 'Indo-Malesian' and 'Antarctic' to describe the origins of the tropical and temperate rainforests respectively. Fresh botanical interpretations are now supported by plate tectonics theory whereby the Australasian plate was part of Gondwanaland, and by microfossil and macrofossil evidence for tropical and subtropical rainforest taxa in southern Australia in late Cretaceous and early Tertiary times. The so-called 'Indo-Malesian' element could have been present in Australia before overland migration and shortdistance dispersal of biota between Australia and northern tropical regions became possible during the Miocene.

It is contended that the evidence for long-distance dispersal of many rainforest taxa is inconclusive. The synthesis of highly integrated and interdependent synusiae, particularly rainforest types that form characteristic patterns throughout the landscape, would have required synchronization of dispersal in space and time that is considered most improbable.

The remarkable concentration and variety of taxa of cycads, conifers and primitive angiosperms, many of them apparently of low vagility, in northeastern Australian rainforests suggest ancient evolutionary links of this region, as part of the Australasian plate in Gondwanan times during the Cretaceous, when angiosperms first appeared in the fossil record.

The abundance of related disjunct rainforest communities revealed by recent floristic classification is interpreted as relictual and dependent on refugia that are relatively old, rather than as recently synthesized communities resulting from stray colonizers.

There is a substantial proportion of tree genera, often apparently of restricted vagility, shared by Australasia and the Indo-Malesian region, especially when data from homologous habitats identified in the field are compared. These affinities would be explicable by early joint inheritance of floras by Australasia and these countries.

Cytotaxonomic studies and ecological interpretation of interspersion of the different floras provide further suggestive evidence for an ancient presence of the rainforests, and under certain edaphic and climatic conditions, for the derivation from them of scleromorphic vegetation types conventionally termed sclerophylls.

The contemporary view, based on inferences in the present paper and other biological evidence summarized by Keast (1981) and Barlow (1981) is of an Australian tropical and subtropical rainforest angiospermous vegetation that began to supplant the coniferous forests during the Cretaceous over the warmer and moister areas. There was co-evolution of cool temperate elements, and of sclerophylls that later became dominant. The different rainforest vegetations tropical monsoonal (raingreen), tropical evergreen, subtropical raingreen and evergreen, warm temperate (lower montane) and cool temperate (upper montane) evergreen - survive today as an 'archipelago of relicts' as the result of climatic and edaphic sifting.

It is suggested that the use of the term 'Indo-Malesia' to denote an ancient northern source of the Australian tropical and subtropical rainforests is no longer valid. The greater concentrations today of certain taxa in the 
Indo-Malesian geographic region may be the result of greater extinctions of their relatives in Australia during aridity in the later Tertiary. Such concentrations may not mean centres of origin as suggested by the age-and-area hypothesis. Younger intrusive elements undoubtedly occur in the wet evergreen rainforests of northern Australia, but their detailed origins are not yet properly understood. Recent intrusive elements seem to be less significant in the dry raingreen forests of northern Australia. It is also suggested that tropical or megatherm (Nix 1982) rainforest and monsoon forest elements be added to the subtropical (mesotherm) and temperate (microtherm) elements already recognized by Barlow (1981) and others as remnants of the ancient Gondwanan flora that once covered Australia. Unlike the temperate element, the tropical elements have affinities with the floras of habitats of northern lands (Webb et al. 1983). The three main relictual types are accordingly 'palaeo-autochthons'. If, as Barlow (1981) concludes, it is valid to apply the term autochthonous to the derived scleromorphic (sclerophyll) element on poor soils and with a seasonally dry climate, and to the derived arid (eremean) element, these are accordingly 'caino-autochthons'. The so-called 'intrusive elements', of which Barlow (1981) lists four, are more recent. It is argued in this paper that the tropical element included as intrusive is not primarily so.

\section{ACKNOWLEDGMENTS}

Dr Helene Martin, University of New South Wales, and Dr Peter Raven, Missouri Botanical Garden, are thanked for commenting on the draft manuscript. They are in no way responsible for the interpretations offered in this paper, which follows that given at the International Botanical Congress at Sydney in August 1981.

\section{REFERENCES}

Balgooy, M. M. J. van (1971). Plant geography of the Pacific as based on the distribution of Phanerogam genera. Blumea, Suppl. 6: 1-222.

Barlow, B. A. (1981). The Australian flora: its origin and evolution. In 'Flora of Australia' (Australian Govt Publ. Service: Canberra) vol. 1, pp. 25-75.

Burbidge, N. T. (1960). The phytogeography of the Australian region. Austral. J. Bot. 8: 75-212.

Carlquist, S. (1974). 'Island Biology' (Columbia Univ. Press: New York).

Carlquist, S. (1981). Chance dispersal. Amer. Sci. 69: 509-516.

Christophel, D. C. (1981). Tertiary megafossil floras of Australia as indicators of floristic associations and palaeoclimate. In Keast, A. (Ed.), 'Ecological Biogeography of Australia' (W. Junk: The Hague) vol. 1, pp. 377-390.

Churchill, D. M. (1973). The ecological significance of tropical mangroves in the early Tertiary floras of southern Australia. Spec. Publ. Geol. Soc. Austral. 4: 79-86.

Davis, M. B. (1981). Quaternary history and the stability of forest communities. In Shugart, H. H., West, D. C. \& Botkin, D. B. (Eds), 'Forest Succession' (Springer-Verlag: New York) pp. 132-153.

Dransfield, J. (1981). Palms and Wallace's Line. In Whitmore, T. C. (Ed.), 'Wallace's Line and Plate Tectonics' (Clarendon Press: Oxford) pp. 43-56.

Daubenmire, R. (1978). 'Plant Geography' (Academic Press: New York).

Galloway, R. W. \& Kemp, E. M. (1981). Late Cainozoic environments in Australia. In Keast, A. (Ed.), 'Ecological Biogeography of Australia' (W. Junk: The Hague) vol. 1, pp. 53-80.

$50417-2312-2$ 
Harris, W. K. (1965). Tertiary microfloras from Brisbane, Queensland. Rep. No. 10. Geol. Survey Qld.

Hekel, H. (1972). Pollen and spore assemblages from Queensland Tertiary sediments. Publ. 355. Palaeont. Paper 30. Geol. Survey Qld.: 1-31.

Herbert, D. A. (1967). Ecological segregation and Australian phytogeographic elements. Proc. Roy. Soc. Queensland 78: 101-111.

Hooker, J. D. (1860). Introductory essay. In 'The Botany of the Antarctic Voyage' (Lovell Reeve: London) part III [Flora Tasmaniae], vol. 1, pp. I-CXXVII.

Kalkman, C. (1979). Dispersal and distribution of Malesian angiosperms. In Larsen, K. \& Holm-Nielsen, L. B. (Eds), 'Tropical Botany' (Academic Press: London) pp. 135-141.

Keast, A. (1981). Origins and relationships of the Australian biota. In Keast, A. (Ed.), 'Ecological Biogeography of Australia' (W. Junk: The Hague) vol. 3, pp. 2000-2050.

Kemp, E. M. (1981). Tertiary palaeogeography and the evolution of Australian climate. In Keast, A. (Ed.), 'Ecological Biogeography of Australia' (W. Junk: The Hague) vol. 3, pp. 31-49.

Kershaw, A. P. (1981). Quaternary vegetation and environments. In Keast, A. (Ed.), 'Ecological Biogeography of Australia' (W. Junk: The Hague) vol. 1, pp. 81-101.

Khan, A. M. (1974). Palynology of Neogene sediments from Papua New Guinea stratigraphic boundaries. Pollen et Spores 16: 265-284.

Kikkawa, J., Monteith, G. B. \& Ingram, G. (1981). Cape York Peninsula: major region of faunal interchange. In Keast, A. (Ed.), 'Ecological Biogeography of Australia' (W. Junk: The Hague) vol. 3, pp. 1695-1742.

Martin, H. A. (1978). Evolution of the Australian flora and vegetation through the Tertiary: evidence from pollen. Alcheringa 2: 181-202.

Martin, H. A. (1981). The Tertiary flora. In Keast, A. (Ed.), 'Ecological Biogeography of Australia' (W. Junk: The Hague) vol. 1, pp. 391-406.

Martin, H. A. (1982). Changing Cenozoic barriers and the Australian palaeobotanical record. Ann. Missouri Bot. Gard. 69(3): 625-667.

Monteith, G. B. (1980). Relationships of the genera of Chinamyersiinae, with description of a relict species from mountains of north Queensland. Pacific Insects 21: 275-285.

Muller, J. (1981). Fossil pollen record of extant angiosperms. Bot. Rev. 47: $1-146$.

Nix, H.'(1982). Environmental determinants of biogeography and evolution in Terra Australis. In Barker, W. R. \& Greenslade, P. J. M. (Eds), 'Evolution of the Flora and Fauna of Arid Australia' (Peacock Press: Adelaide) pp. 47-66.

O'Neill, G. (1980). New light on the origins of Australia's flora. Ecos 24: 3-8.

Partridge, A. D. (1976). The geological expression of eustacy in the Early Tertiary of the Gippsland Basin. APEA Journal 16: 73-78.

Pijl, L. van der (1972). 'Principles of Dispersal in Higher Plants' (SpringerVerlag: Berlin) Edn 2.

Raven, P. H. (1979). Plate tectonics and southern hemisphere biogeography. In Larsen, K. \& Holm-Nielsen, L. B. (Eds), 'Tropical Botany' (Academic Press: London) pp. 3-24.

Raven, P. H. \& Axelrod, D. I. (1974). Angiosperm biogeography and past continental movements. Ann. Missouri Bot. Gard. 61: 539-673. 
St John, H. (1973). 'List and Summary of the Flowering Plants in the Hawaiian Islands'. Mem. No. 1. (Pacific Tropical Botanic Garden: Lawai, Hawaii).

Schulz, J. P. (1960). Ecological studies on rainforest in Northern Suriname. Verh. Kon. Ned. Akad. Wetensch., Afd. Natuurk., Tweede Sect. 53: 1-367.

Southwood, T. R. E. (1977). Habitat, the templet for ecological strategies? $J$. Animal Ecol. 46: 337-365.

Specht, R. L. (1981a). Major vegetation formations in Australia. In Keast, A. (Ed.), 'Ecological Biogeography of Australia' (W. Junk: The Hague) vol. 1, pp. 163-297.

Specht, R. L. (1981b). Evolution of the Australian flora: some generalizations. In Keast, A. (Ed.), 'Ecological Biogeography of Australia' (W. Junk: The Hague) vol. 1, pp. 783-805.

Steenis, C. G. G. J. van (1962). The land-bridge theory in botany. Blumea 11: 235-372.

Steenis, C. G. G. J. van (1979). Plant geography of east Malesia. J. Linn. Soc., Bot. 79: 97-178.

Takhtajan, A. (1969). 'Flowering Plants: Origin and Dispersal' (Oliver \& Boyd: Edinburgh).

Thorne, R. F. (1972). Floristic relationships between tropical Africa and tropical America. In Meggers, B. J., Ayensu, E. S. \& Duckworth, W. D. (Eds), 'Tropical Forest Ecosystems in Africa and South America; A Comparative Review' (Smithsonian Inst. Press: Washington) pp. 27-47.

Walker, D. \& Wilson S. R. (1978). A statistical alternative to the zoning of pollen diagrams. J. Biogeogr. 5: 1-21.

Webb, L. J. (1959). A physiognomic classification of Australian rainforests. $J$. Ecol. 47: 551-570.

Webb, L. J. (1968). Environmental relationships of the structural types of Australian rainforest vegetation. Ecology 49: 296-311.

Webb, L. J. (1978). A general classification of Australian rainforests. Austral. Pl. 9: 349-363.

Webb, L. J. \& Tracey, J. G. (1981a). Australian rainforests: patterns and change. In Keast, A. (Ed.), 'Ecological Biogeography of Australia' (W. Junk: The Hague) vol. 1, pp. 607-694.

Webb, L. J. \& Tracey, J. G. (1981b). The rainforests of northern Australia. In Groves, R. H. (Ed.), 'Australian Vegetation' (Cambridge Univ. Press: Cambridge) pp. 67-101.

Webb, L. J., Tracey, J. G. \& Williams, W. T. (1984). A floristic framework of Australian rainforests. Austral. J. Ecol. 9(3): 169-198.

Whitmore, T. C. (Ed.) (1981). 'Wallace's Line and Plate Tectonics' (Clarendon Press: Oxford).

Wickens, G. E. (1979). Speculations on long distance dispersal and the flora of Jebel Marra, Sudan Republic. Kew Bull. 31(1): 105-150.

Wiley, E. O. (1980). Phylogenetic systematics and vicariance biogeography. Syst. Bot. 5: 194-220. 